\title{
NIH strives to keep resource sharing alive
}

[WASHINGTON] The US National Institutes of Health (NIH) last week called on universities to "take every reasonable step" to ensure the free sharing of research tools between scientists.

Issuing guidelines to university officials who negotiate licences and agreements for sharing research tools, the NIH said such officials should do everything possible to make research tools discovered by NIHfunded investigators freely and broadly available. It says this mandate does not clash with a 19-year-old law that opened the door for universities to issue exclusive licences on government-funded inventions.

The guidelines urge universities to speed up the transfer of tools to academic scientists elsewhere, and to private companies that are not using them for direct commercial purposes. They also say that exclusive licences for research tools should "generally be avoided", except when the licensee plans to make the tool widely available at an affordable cost, or when the licensor keeps the rights to do so.

Institutions are urged to avoid patenting research tools. The guidelines say these rarely require patent protection, as further research, development and private investment are not needed to realize their usefulness. The "indiscriminate" patenting of such tools is "antithetical" to the goal of getting taxpayerfunded inventions out to the public.

The guidelines were developed by the NIH's Office of Technology Transfer on the recommendation of a working group that reported last year to $\mathrm{NIH}$ director Harold Varmus (see Nature 393, 505; 1998).

The NIH has repeatedly expressed concern about impediments to the sharing of research tools, and the guidelines mark the agency's first formal written policy on the issue. They are due to be published in the Federal Register this week, and will be open for public comments for 90 days before a final version is draw up.

The guidelines chart a fine line between encouraging the sharing of research tools and the provisions of the Bayh-Dole Act, a 1980 law that gave universities ownership of government-funded inventions and encouraged them to license them in order to commercialize them for public benefit.

One NIH official who helped draft the guidelines says the Bayh-Dole Act should not be read as an eleventh commandment "thou shalt patent and exclusively license" that precludes the liberal sharing of research tools. "Commercialization is a good thing, but we want [universities] to commercialize without encumbering future research," the official says. "It's NIH's view that you can accomplish both with strategic licensing."

The guidelines call for "thoughtful, strategic" implementation of the Bayh-Dole Act on a case-by-case basis, in order to strike a balance between fostering product development and making sure researchers have access to the cell lines and clones they need.

Cases in which a technology needs to be licensed exclusively in order to develop it as a product, but where it is clear that it should be made widely available as a research tool, will have to be worked out with "creative licensing", adds the NIH official. "This is a road map but not a solution for every problem."

Rebecca Eisenberg, a patent-law expert at the University of Michigan Law School in Ann Arbor and chair of last year's working group on research tools, points out that the guidelines do not exclude the possibility that "real winner[s]" can be licensed on lucrative terms. But she thinks the NIH is "trying to stop that from being the default position".

The guidelines also urge technologytransfer offices to scrutinize the agreements under which they obtain research tools from other non-profit institutions or industry. Officials are "expected to avoid" signing agreements likely to keep them from being able to broadly disseminate further tools that might arise from the research. Excessive publication delays, requirements for editorial control or pre-publication approval, and withholding of data, are all "unacceptable", the guidelines say.

The guidelines were praised by university technology-transfer officials, many of whom were consulted during their drafting, but some aspects are likely to raise concern at institutions where the Bayh-Dole Act has been read as a licence to make as much money as possible from technology transfer. Many institutions prize money generated in this way, as its uses are unrestricted.

Other university officials say that it is not loss of revenue, but loss of control, that worries them. Fred Erbisch, director of the Office of Intellectual Property at Michigan State University in East Lansing, says that the NIH's call to institutions to avoid patenting research tools "bothers me".

The university is still smarting, he says, from an incident seven years ago, when genetic material was loaned under very loose terms to a company that was sponsoring unrelated research at the university. That company patented it, with the result that the molecular biologist at the university who is the inventor can't share it with colleagues in the laboratory next door.

Institutions receiving $\mathrm{NIH}$ funding for their investigators are not required to adopt the guidelines. But the agency exhorts both academia and industry to implement them.

That can't be assumed in the private sector. "Our position and the NIH's are not necessarily the same," says David Schmickel, the patent and legal counsel for the Biotechnology Industry Organization. "We'll be considering the guidelines in the light of our best interests, which also have a significant public-health benefit."

Some scientists feel that the NIH should go further than issuing guidelines. Michael Green, a Howard Hughes Medical Institute investigator at the University of Massachusetts Medical Center in Worcester, says that, while they go "in the right direction", they "will not be sufficient to solve the problem".

"They should mandate them for all NIHfunded investigators and then [the NIH should] take some kind of responsibility for enforcing them," Green says. After several years of failed attempts to obtain three published plasmids and one published cell line from fellow investigators, he says he has now given up.

The guidelines are available on the web at www.nih.gov/od/ott and comments may be sent tonihott@od.nih.gov MeredithWadman

\section{Hubble spots giant cyclonic storm on Mars}

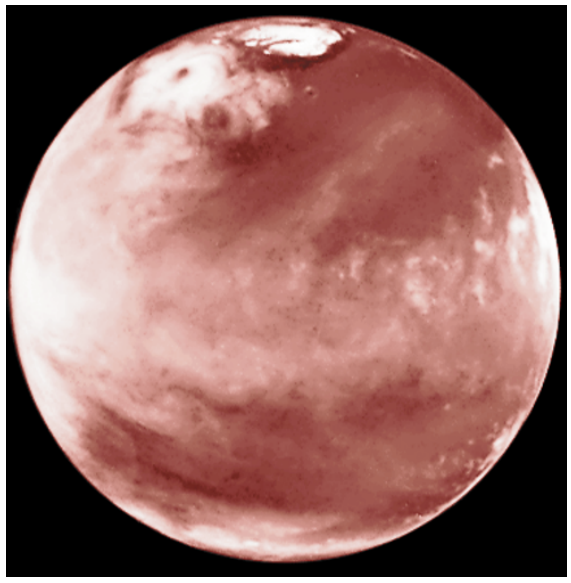

^ ๑ 1999 Macmillan Magazines Ltd
[LONDON] A giant cyclonic storm was seen raging in the northern polar regions of Mars last month by the Hubble Space Telescope. The storm, which was 900 miles long and 1,100 miles wide, is the largest ever detected on the planet. It was largely dust-free, and is believed to have been composed of clouds of water ice, similar to storm systems on Earth. The eye of the storm was $\mathbf{2 0 0}$ miles across.

The storm can be seen to the left of the polar ice cap in the picture. The dark spot above the cloud is the extinct volcano Ascraeus Mons, which is 16 miles high and 250 miles across. The storm, detected by Hubble's Wide Field Planetary Camera, has not been seen since and may be over. E.M. 